\title{
Articles
}

\section{Judicial Self-Government and Judicial Independence: the Political Capture of the General Council of the Judiciary in Spain}

\author{
Aida Torres Pérez ${ }^{*}$
}

\begin{abstract}
The General Council of the Judiciary is the main institution of judicial self-government in Spain. It was established to ensure the external independence of the judiciary, and in particular the independence of the judiciary vis-à-vis the executive branch of government. To what extent does the Judicial Council manage to fulfill its goal? First, the evolution of the Judicial Council will be presented in order to understand the principal reforms and reasons behind its creation. Next, the impact of the Judicial Council upon judicial independence, as well as accountability, transparency, and public confidence will be critically examined in order to assess its contribution to judicial legitimacy. In the end, it will be argued that the politicization of the Judicial Council has hindered it from protecting judicial independence from partisan interests, and has contributed to undermining public confidence in the judiciary.
\end{abstract}

\footnotetext{
* Associate Professor of Constitutional Law at Pompeu Fabra University. Email - aida.torres@upf.edu. The research leading to this article has received funding from the European Research Council (ERC) under the European Union's Horizon 2020 research and innovation programme (grant no. 678375- JUDI-ARCH-ERC-2015STG).
} 


\section{A. Introduction}

The General Council of the Judiciary (hereinafter referred to as the Judicial Council) is the main institution of judicial self-government in Spain. It was established by the 1978 Spanish Constitution, ${ }^{1}$ enacted in the return to democracy after Franco's dictatorship. The Judicial Council was introduced following the model of the Consiglio Superiore della Magistratura in Italy, and the Conseil Superieur de la Magistrature in France, for there was no precedent in the Spanish constitutional history. ${ }^{2}$ The Judicial Council is defined as a constitutional body of judicial self-government, yet it does not form part of the judiciary. Its main goal is to ensure the external independence of the judiciary, and in particular the independence of the judiciary vis-à-vis the executive branch of government. The question researched in this work is the extent to which the Judicial Council manages to fulfill its goal.

Judicial independence is the guiding constitutional principle behind the design of the judiciary. Indeed, the notion that courts must be free from external pressure lies at the core of the justification of the power to adjudicate that is accorded courts and distinguishes them from the power exercised by other public authorities such as the legislative or the executive powers. ${ }^{3}$ Notwithstanding, other values, such as accountability and transparency, are extremely important for judicial legitimacy. Independence is thus regarded as a necessary, but not sufficient, condition for the legitimacy of courts.

This analysis aims to assess the Judicial Council's contribution or lack thereof in promoting these values. It will be argued that the politicization of the Judicial Council has hindered it from securing judicial independence from partisan interests. The 2017 EU Justice Scoreboard ${ }^{4}$ shows that the perceived independence of Spanish courts and judges by the general public is among the lowest in the EU (just above Slovakia and Bulgaria). The main reason stated for this negative perception is interference or pressure from government and politicians. Indeed, the public's perception that the Council is highly politicized has

\footnotetext{
${ }^{1}$ Constitution Article 122.

${ }^{2}$ Manuel Jose Terol Becerra, El Consejo General del Poder Judicial 53-61 (1990); Luis Aguiar de Luque, Continuidad y reforma en el régimen jurídico del Consejo General del Poder Judicial, in INDEPENDENCIA JUDICIAL Y ESTADO CONSTITUCIONAL. El GobieRno JUdicial 11-12 (Luis Aguiar de Luque ed., 2016).

${ }^{3}$ Aida Torres Pérez, From Judicial Independence to Interdependence in the International Sphere, 24(4) MAASTRICHT JoURNAL OF EUROPEAN AND COMPARATIVE LAW 462, 464 (2017).

${ }^{4}$ European Commission, The 2017 EU Justice Scoreboard, at 37-38, http://europa.eu/rapid/press-release_IP-17890_es.htm
} 
profoundly damaged its sociological legitimacy, and hence that of the judiciary as a whole. The Judicial Council has been politically captured to the point of dysfunction. ${ }^{5}$

In what follows, the creation and evolution of the Judicial Council will first be presented to understand the principal changes and reasons behind them. Second, the impact of the Judicial Council upon judicial independence, as well as accountability, transparency, and public confidence will be critically examined in order to assess its contribution to judicial legitimacy. Finally, we will conclude with reflections on the Judicial Council from the perspective of the separation of powers.

\section{B. The General Council of the Judiciary: the rationale for its creation and evolution over time}

Following Franco's dictatorship, ensuring external judicial independence became the main rationale for the creation of a Judicial Council. External judicial independence requires that judges be free from any interferences or influences coming from other public powers and private actors, whereas internal independence refers to the potential influences coming from other judges or courts. The principal concern was minimizing the potential for interference and pressures upon judges and courts from the executive power, as confirmed by the constitutional debates. ${ }^{6}$ Hence, the Judicial Council was created to transfer functions that might compromise judicial independence, such as the appointment, promotion, or discipline of judges, from the executive to an independent body.

Over the drafting process of the Constitution, there were several proposals to include further provisions about the basic principles of the Council, a broader definition of its functions, or the regime of incompatibilities of its members. And yet, the framers opted for a minimal constitutional regulation and the referral to an Organic Law ${ }^{7}$ as the instrument to develop the composition and functions of this institution, following the French and the Italian model. ${ }^{8}$

\footnotetext{
${ }^{5}$ Aguiar de Luque, supra note 2; Diego Íñiguez Hernández, La reforma del Consejo General del Poder Judicial en España. Noticia de otra reforma fallida, 7 CUADERNOS MANUEL GIMÉNEZ ABAD 147 (2014).

${ }^{6}$ Terol Becerra, supra note 2, at 53; Víctor Ferreres Comella, The Constitution of SPAin 210 (2013).

${ }^{7}$ The Organic Law is a specific type of legislation that needs the support of an absolute majority of Congress to be enacted.

${ }^{8}$ Terol Becerra, supra note 2, at 58-59.
} 
The judiciary is also governed, subordinate to the Judicial Council, by the "Administrative Chambers" (Salas de Gobierno) of the Supreme Court, the National Audience ${ }^{9}$ and the High Courts of Justice, as well as the Presidents of each court. The Administrative Chambers exercise managerial and organizational functions and are vested with disciplinary powers. Although the exercise of these functions could well be examined from the perspective of internal judicial independence, this analysis will focus on the risks for external judicial independence. ${ }^{10}$

The Judicial Council was first regulated by Organic Law 1/1980, of 10 January 1980, on the General Council of the Judiciary. Soon thereafter, following the victory of the Socialist Party in the general elections, this Organic Law was derogated and the regulation of the Judicial Council was reorganized and established by Organic Law 6/1985, 1 July, on the Judicial Power (LOPJ). The legislative regulation of the Council has continued to evolve over time with significant changes being introduced in $1994,{ }^{11} 2001,{ }^{12}$ and $2013 .{ }^{13}$ Further reforms were enacted in 2014 and $2015 .{ }^{14}$ We will now examine the main changes and the reasons behind them in, first, the composition of the Council and appointment of its members and, second, the powers this institution holds.

\section{Composition and appointment}

According to Article 122(3) of the Constitution, the Judicial Council includes the President of the Spanish Supreme Court and twenty other members. The other members are a combination of mostly judges and some other jurists: twelve members are appointed among judges while eight are selected among jurists whose competence is recognized and possess more than fifteen years of professional experience. Council members are appointed for a non-renewable period of five years. The Council is presided by the President of the Supreme Court, who is elected by the Council members.

\footnotetext{
${ }^{9}$ The "Audiencia Nacional" is a court with jurisdiction over the whole country specialized on certain subject matters, such as terrorism.

${ }^{10}$ Rafael Bustos Gisbert, Encuesta sobre la Independencia del Poder Judicial, 38 TEORÍA Y REALIDAD CONSTITUCIONAL $15,18-19$ (2016) claimed that this form of internal independence has not raised serious problems.

${ }^{11}$ Organic Law 16/1994, 8 November, on the amendment of Organic Law 6/1985 on the Judicial Power.

${ }^{12}$ Organic Law 2/2001, 28 June, on the composition of the General Council of the Judiciary.

${ }^{13}$ Organic Law 4/2013, 24 June, on the amendment of the General Council of the Judiciary.

${ }^{14}$ Organic Law 4/2014, 11 July; and Organic Law 7/2015, 21 July.
} 
The appointment process has undergone significant changes over time and represents one of the most sensitive, contested issues regarding the institutional design of the Judicial Council. ${ }^{15}$ According to the Constitution, the eight jurists are to be elected by the Congress (four) and the Senate (four), by a three-fifths majority of each Chamber. ${ }^{16}$ The constitutional text is vague, however, regarding the appointment of the twelve judicial members; it does not specify who shall appoint them, referring only to the terms set by the Organic Law.

Initially, Organic Law $1 / 1980$ provided that the twelve judges would be elected by judges, but this model did not last long. In 1985, the Organic Law passed after the Socialists were elected stipulated that the twelve judges were to be appointed by Congress and Senate (six by each chamber). The political motivation for this amendment was the dominance of a single conservative judicial association in the election of the first twelve judicial Council members. ${ }^{17}$ In response, the Socialist government, which gained a majority in Congress in the 1982 elections, launched a reform of the selection process for the Council members that transferred appointment power to the Parliament.

This reform was challenged and went to the Constitutional Court. ${ }^{18}$ The Court upheld the constitutionality of the new law on the grounds that the Constitution did not specify how the twelve judicial members would be appointed. At the same time, however, the Constitutional Court voiced some concern regarding the shift of power to the legislature, noting that the Constitution stated that eight members of the Judicial Council were to be elected by Parliament. Had the will of the framers been that Parliament elected all twenty regular members, this power would have been directly attributed to Parliament. The Constitutional Court also warned against the risk of subjecting the appointment process to partisan politics in the long run. ${ }^{19}$

\footnotetext{
${ }^{15}$ Manuel Gerpe Landín \& Miguel Ángel Cabellos Espiérrez, La Reforma Permanente: El Consejo General del Poder Judicial a la Búsqueda de un Modelo, 103 ReVISTA ESPAÑOLA DE DERECHO CONSTITUCIONAL 13 (2015); Ascensión Elvira Perales, Composición y Elección de los Miembros del Consejo General del PoderJudicial, in INDEPENDENCIA JUDICIAL Y Estado Constitucional. El Gobierno Judicial 27, 28-36 (Luis Aguiar de Luque ed., 2016).

${ }^{16}$ The Spanish Parliament is composed of two Chambers: the Congress of Deputies, which represents the people; and the Senate, which is defined as the Chamber of territorial representation.

${ }^{17}$ Asociación Profesional de la Magistratura (APM). Rosario Serra Cristóbal, La Elección de los Miembros del Consejo General del Poder Judicial. Una Propuesta de Consejo más Integrador e Independiente, 31 TEORía Y ReALIDAD CONSTITUCIONAL 277, 301 (2013); íñiguez Hernández, supra note 5, at 148.

${ }^{18}$ STC 108/1986, 29 July 1986.

${ }^{19}$ Id. para. 13
} 
In 1996 the Popular Party won the general elections, and in 2000 it obtained absolute majority in Congress. A new mixed appointment process was enacted in 2001, according to which the twelve judges would be elected by Parliament from a pool of at most thirty-six candidates nominated by judicial associations or cohorts of judges that represented at least $2 \%$ of the total number of judges in active service. ${ }^{20}$ The selection of the thirty-six candidates was to be determined by the number of members of each judicial association and the number of non-affiliated judges. This mixed model therefore granted judges the power to nominate candidates and reserved the final decision for Parliament.

This amendment attributed a prominent role to the judicial associations in the appointment process, mirroring the actual practice, since judicial associations already placed a central role in selecting the candidates. According to the data provided by the Council, ${ }^{21}$ between 2004 and 2017 the percentage of associated judges has slightly varied between $53 \%$ and $55 \% .{ }^{22}$ The most influential judicial associations are: Professional Association of the Magistrature (Asociación Profesional de la Magistratura, APM) and Judges for Democracy (Jueces y Juezas para la Democracia, JJpD). The former is regarded as conservative, and ideologically close to the Popular Party and the latter as progressive and close to the Socialist Party. ${ }^{23}$

The configuration of the Council selected in 2001 reveals their importance. Although associated judges make up about half of the total, nine out of twelve of the elected members belonged to a judicial association. In the subsequent term, in 2008, all the elected candidates did. ${ }^{24}$

In addition, the requirement of a three-fifths majority in Congress and the Senate to elect all Council members, rather than promoting broad consensus within Parliament, has led to the practice of allocating the positions to the two main political parties. Usually, the Socialist and the Popular Party have distributed the twenty candidates between them, with occasional inclusion of members from a few smaller political groups, depending on their

\footnotetext{
${ }^{20}$ Article 112 LOPJ.

${ }^{21}$ http://www.poderjudicial.es/cgpj/es/Temas/Estadistica-Judicial/Plan-Nacional-de-Estadistica-Judicial/Recursoshumanos/Asociaciones-Judiciales-Profesionales

${ }^{22}$ In 2017, out of a total of 5.364 judges in active service, 2.977 belonged to judicial associations.

${ }^{23}$ In 2017, APM had 1.328 members, and JJpD 523. There are two other important judicial associations in terms of their membership: Asociación Francisco de Vitoria (797) and Foro Judicial Independiente (324).

${ }^{24}$ Six belonged to Asociación Profesional de la Magistratura; five (and the President) to Jueces y Juezas para la Democracia, and one to the Asociación de Jueces Francisco de Vitoria, see Serra Cristóbal, supra note 17, at 303.
} 
respective strength in the Congress and the Senate. Despite this informal arrangement, it is not always easy for the parties to reach agreement.

For instance, in 2008 the Council was only renewed after a year and a half delay of shameful political scuffling between the main parties over control of the Council. In the end, the Socialist Party nominated 9 members, as did the Popular Party, while the Basque Nationalist Party and Convergènca i Unió (the former nationalist Catalan party) advanced one member each. Moreover, even though the choice of the President of the Council and the Supreme Court corresponds to the Council, in practice this tends to be determined through political negotiation. For instance, in 2008, the newspapers reported that President Rodríguez Zapatero had proposed Carlos Dívar as President of the Council, and that Mariano Rajoy, the opposition leader at the time, had accepted. ${ }^{25}$

As a consequence, the Council is perceived as politicized, hence undermining its legitimacy, and the perceived lack of legitimacy pervades the judiciary. This situation has led to political debate over reforming the appointment process of Council members. In 2011, the Popular Party defeated the Socialist in the general elections and obtained absolute majority in Congress. The new government presided by Mariano Rajoy launched a reform of the Judicial Council by appointing an institutional commission of experts to draft a proposal. Among the novelties they proposed, it was suggested that the twelve judicial members be elected by their peers, to improve the proportionality of the election system and reduce the dominance of judicial associations. ${ }^{26}$

Notwithstanding, Organic Law 4/2013, enacted without any opposition support, did not follow the institutional Commission proposal, reserving the election of the judicial members for Parliament. The role of judicial associations was slightly revised, but remained very much present in practice. Indeed, current Article 567(2) LOPJ sets forth: "Each Chamber shall elect, by a majority of three fifths of its members, ten members, four among jurists of recognized competence with more than fifteen years of professional experience, and six judges, according to Chapter II of the Present Title."

Article 572 LOPJ and the following clauses regulate the process through which judges may submit their candidature. To be eligible for candidacy, judges must provide the support of at least twenty-five members of the judicial profession in active service, or the support of a judicial association legally constituted. Hence, in order to promote the participation of judges from across the judicial spectrum, the number of backers was reduced and

\footnotetext{
${ }^{25}$ http://www.rtve.es/noticias/20080922/psoe-propone-carlos-divar-como-presidente-del-cgpj-fernando-rosacomo-vicepresidente/161666.shtml; http://www.lavanguardia.com/politica/20080922/53544647489/zapateropropone-a-carlos-divar-como-presidente-del-cgpj-y-del-tribunal-supremo.html

${ }^{26}$ Elvira Perales, supra note 15 , at $31-32$.
} 
associations may now support candidates, instead of directly submitting them. ${ }^{27}$ De iure, the election is in the control of Parliament while, de facto, judicial associations play still an important role. This model has been contested because of both its questionable compatibility with the constitution and the consequences for the Council's institutional independence, which will be discussed in section $\mathrm{C}$.

\section{The constitutional functions of the Judicial Council}

The Constitution directly attributes a set of powers to the Judicial Council: appointing, promoting, inspecting, and disciplining judges. ${ }^{28}$ These functions are all very sensitive from the perspective of judicial independence, and for this reason they were removed from the executive and allocated to the newly created Judicial Council. ${ }^{29}$ Indeed, the powers attributed to the Council would otherwise be exercised by the Ministry of Justice. Moreover, the Constitution grants the Judicial Council the nomination of two candidates to the Constitutional Court ${ }^{30}$ and the right to be heard before the General Prosecutor is appointed. $^{31}$

\section{Judicial appointments and promotion}

Entry level judicial appointments are made based on merit. The selection process consists of a set of competitive exams followed by a6-month course on practice and theory at the Judicial Academy, and then a training period in court. The Judicial Council oversees the Judicial Academy. There is longstanding debate over the need to reform the model of judicial selection, since the exams focus on the candidates' faculty of memory more than the intellectual, analytical, and argumentative skills also needed to exercise the judicial function. Notwithstanding the debate, the model has changed very little over time. Whereas the process of judicial appointment has evolved in other countries, it has grown obsolete in Spain in the face of the transformations and complexity of current society and is now ill-designed to select the candidates that might best perform the judicial function. ${ }^{32}$

\footnotetext{
${ }^{27}$ Gerpe Landín \& Cabellos Espiérrez, supra note 15.

${ }^{28}$ Constitution Article 122(2).

${ }^{29}$ Ferreres Comella, supra note 6, at 211.

${ }^{30}$ Constitution Article 159(1).

${ }^{31}$ Constitution Article 124(4).

${ }^{32}$ Alejandro Saiz Arnaiz, la Reforma del Acceso a la Carrera Judicial en España: Algunas Propuestas (2007); Pascual Ortuño Muñoz, El Acceso a la Judicatura, in INDEPENDENCIA JUdICIAL y ESTADo CONSTITUCIONAL. EL ESTATUTO DE LOS JUECES (Maribel González Pascual \& Joan Solanes Mullor eds., 2016).
} 
The Judicial Council is also in charge of promoting judges over their careers. The general criteria involve the principles of merit and capacity. The legislative framework, however, leaves considerable margin for discretion to the Judicial Council in appointing judges to high courts and administrative positions. No such discretion exists at the lower court level, where appointments and promotion are determined by law and seniority is the main element. At higher levels, though, appointments are largely discretionary, as long as the candidates fulfill certain requirements. ${ }^{33}$ Discretionary appointments include: the president, presidents of chambers, and judges of the Supreme Court; the president of the National Audience and its chambers; the presidents of High Courts of Justice and their chambers; and the presidents of Provincial Courts. Some of those positions are purely jurisdictional, while others involve managerial and organizational responsibilities.

The appointment power lies with the Plenary of the Judicial Council and there is significant risk that in practice the selection of candidates for these positions be determined by ideological allegiance. ${ }^{34}$ The wide margin for discretion leaves too much room for arbitrary decisions based on political views. ${ }^{35}$ Some legislative amendments have been enacted to address this risk: Organic Law 19/2003, 23 December, emphasized the principles of merit and capacity as the main elements for consideration in appointment and promotion decisions; and Organic Law 2/2004, 28 December, raised the number of votes to a threefifths majority for the appointment of Supreme Court judges and presidents of chambers, as well as presidents of High Courts to encourage the search of broad consensus within the Council. The 2013 reform of the LOPJ, however, replaced the qualified majority with a simple majority for the appointment of high judicial positions. The alleged purpose of this reform was to simplify Council operations, but in practice its consequence has been determining appointments and promotion without need to reach agreement with the minority within the Council. ${ }^{36}$

\section{Inspection and disciplinary regime}

The Judicial Council performs the function of monitoring all courts to supervise the administration of justice. ${ }^{37}$ Monitoring functions are also attributed to the Presidents of

\footnotetext{
${ }^{33}$ Itziar Gómez Fernández, Nombrar como Manifestación del Poder del Consejo: Discrecionalidad e Independencia del Juez, in INDEPENDENCIA JUdiCIAL Y ESTADo CONSTITUCIONAL. EL GobIERNo JudiCIAL 69 (Luis Aguiar de Luque ed., 2016).

${ }^{34}$ Íñiguez Hernández, supra note 5.

${ }^{35}$ See the discussion undersection C.I.3 below.

${ }^{36}$ Diego íñiguez Hernández, La Contrarreforma del Consejo General del Poder Judicial, 34 TEORÍA Y REALIDAD CONSTITUCIONAL 333, 340-341 (2014).

${ }^{37}$ JOHN BELL, JUdICIARIES WITHIN EUROPE. A COMPARATIVE REVIEW 184-186 (2006).
} 
the Supreme Court, the National Audience, and the High Courts of Justice. ${ }^{38}$ The inspections focus on aspects such as the number of cases decided and pending and the duration of proceedings.

The disciplinary power corresponds to the Judicial Council. The Administrative chambers and court presidents are also granted disciplinary power for minor offenses. ${ }^{39}$ Organic Law $4 / 2013$ modified the disciplinary procedures. ${ }^{40}$ The new system is aimed at strengthening the separation between the investigation and the decision phases preceding sanctions and furthering the guarantees of the administrative proceedings based on the accusatory principle.

In this vein, Organic Law 4/2013 created a new body, the "prosecutor of the disciplinary action" (Promotor de la Acción Disciplinaria) and amended the Disciplinary Commission. The Prosecutor, who is appointed by the Plenary among the magistrates of the Supreme Court and those with more than twenty-five years in the judicial career, is in charge of assembling the facts for disciplinary proceedings. ${ }^{41}$ The Disciplinary Commission is composed of seven members elected by the Plenary among its own members (four judges and three jurists). ${ }^{42}$ Accordingly, the different functions of instruction and sanction are delegated to different bodies.

\section{The Impact of the Judicial Council on the independence, accountability, transparency, and public confidence in the judiciary}

The normative legitimacy of courts as institutions vested with the power of adjudication is heavily grounded on their independence, which demands that the judges who apply the law to the disputes brought before them be free from undue pressures or influences from external actors. At the same time, their legitimacy might also be contingent on other values, such as accountability or transparency.

\footnotetext{
${ }^{38}$ Articles 171-172 LOPJ.

${ }^{39}$ Articles 414-427 LOPJ.

${ }^{40}$ Gema Rosado Iglesias \& Ana Espinosa Díaz, Independencia Judicial y Poder Disciplinario, in INDEPENDENCIA JUDICIAL y Estado Constitucional. El GobieRno Judicial 101, 110-114 (Luis Aguiar de Luque ed., 2016).

${ }^{41}$ Article 606 LOPJ.

${ }^{42}$ Article 603 LOPJ.
} 
Subjecting judges to accountability mechanisms, however, could also pose a threat to judicial independence. ${ }^{43}$ Those who have the power to hold judges accountable might use the power to influence or interfere with the judicial function. ${ }^{44}$ And yet, the notion of independence does not involve being free from any constraint, but only from those constraints that might distort the decision-making process by including considerations extraneous to adjudication, such as political allegiances or personal gain. Judicial independence does not run counter to all forms of accountability, as long as the constraints imposed do not open a path to "undue" influence or pressure. ${ }^{45}$ In addition, transparency has gained momentum as a value associated with good governance and democratic legitimacy, and in the judicial realm it might actually contribute to enhancing both independence and accountability.

We are not only interested in the normative legitimacy of courts, but also in their sociological legitimacy. ${ }^{46}$ In a descriptive or sociological sense, following Weber, legitimacy implies that a legal system or institution is perceived as legitimately binding by those under its jurisdiction, and thus making a justified claim to obedience. In this sense, legitimacy refers to actual the beliefs held by individuals. ${ }^{47}$ Courts not only need to be independent, but also be perceived as independent in order to gain support from key constituencies. Hence, this section will analyze the impact of the Judicial Council upon the independence, accountability, transparency, and public confidence in the judiciary.

\section{The Judicial Council and judicial independence}

The main rationale behind the Judicial Council is secure the independence of the judiciary from external influence, and in particular that of the executive power. To what extent does the Council fulfill this goal? The mere creation of an ad hoc body and the transfer of sensitive functions, such as judicial appointments, promotion, and the disciplinary regime

\footnotetext{
43 Francesco Contini \& Richard Mohr, Reconciling Independence and Accountability in Judicial Systems, 3(2) UtRECHT LAW REVIEW 26, 27-29 (2007); Stephen B. Burbank, Judicial Independence, Judicial Accountability, and Interbranch Relations, 95 THE GEORGETOWN LAW JOURNAL909 (2007).

${ }^{44}$ Charles G. Geyh, Rescuing Political Accountability from the Realm of Political Rhetoric, 56 CASE WESTERN RESERVE LAW REVIEW 911-935, 912 (2006).

45 John A. Ferejohn \& Larry D. Kramer, Independent Judges, Dependent Judiciary: Institutionalizing Judicial Restraint, 77 NEW YORK UNIVERSITY LAW REVIEW 962 (2002).

46 Jens Steffek, The Legitimation of International Governance: A Discourse Approach, 9 EUROPEAN JOURNAL OF INTERNATIONAL RELATIONS 249, 253-254 (2003); Daniel Bodansky, The Legitimacy of International Governance: A Comming Challenge for International Environmental Law?, 93 AMERICAN JOURNAL OF INTERNATIONAL LAW, 596, 601603 (1999).

${ }^{47}$ Torres Pérez, supra note3, at 464.
} 
are not sufficient if this body lacks independence from other actors, such as government, parliament or judicial organizations. To answer the questions of how autonomous the Judicial Council is vis-à-vis external actors (and especially the political branches) and what the implications for the judiciary are, we will focus on three issues: the appointment of the members of the Council; the Council's internal functioning and structure; and its discretionary power to appoint judges to high posts.

Indeed, the most recent Report by the Group of States against Corruption (GRECO) of the Council of Europe, issued in 2018, ${ }^{48}$ was very critical of the Council in these regards and denounced Spain's failure to meet the recommendations of the previous GRECO Report issued in $2013 .^{49}$ In particular, the GRECO Report recommended "carrying out an evaluation of the legislative framework governing the General Council of the Judiciary and of its effects on the real and perceived independence of this body from any undue influence, with a view to remedying any shortcomings identified. ${ }^{150}$ In 2018, it concluded that this recommendation had not been implemented. ${ }^{51}$

\section{The politicization of the Judicial Council through the appointment process}

The appointment of the twenty members of the Judicial Council corresponds to Parliament by a three-fifths majority. The goal of this super-majority is to require broad consensus among the political parties represented in Parliament regarding the candidates to be appointed. In practice, however, the three-fifths super-majority requirement has led to a quota system. ${ }^{52}$ As explained above, the appointment process in Spain is dominated by the two main political parties and the two main judicial associations. The Council's composition is the outcome of political negotiation between the Socialist and Popular parties regarding the number of candidates to be assigned to each party according to their strength in Parliament.

\footnotetext{
${ }^{48}$ Group of States against Corruption, Fourth Evaluation Round, Corruption prevention in respect of members of parliament, judges and prosecutors, GrecoRC4(2017)18, Strasbourg, 8 December 2017 (publication date 3 January 2018).

${ }^{49} 2018$ GRECO Report, supra note 48.

${ }^{50}$ Id. para. 34, recommendation $v$.

${ }^{51}$ ld. para. 35

52 Bustos Gisbert, supra note 10, at 30; Juan Fernando López Aguilar, Encuesta sobre la Independencia del Poder Judicial, 38 TeOría y ReAlidad Constitucional 15, 31 (2016); Pablo Lucas Murillo de la Cueva, Encuesta sobre la Independencia del Poder Judicial, 38 TEORía Y REALIDAD CONSTITUCIONAL 15, 32 (2016).
} 
When the Council was renewed in 2013 , the same pattern was followed: the two primary political parties divided the number of candidates between themselves, offering three to minority parties. Among the judicial members appointed, nine of the twelve belonged to the two main judicial associations ${ }^{53}$ while the remaining three were not associated. Subsequently, the appointed members elected as President the person that had already been announced by the media, Carlos Lesmes, who participated in the commission that prepared the 2013 legislative amendment and had served as director general of the Ministry of Justice under two legislatures (1996-2004). ${ }^{54}$

Clearly, then, this model has not prevented ideological polarization within the Council that undermines its purpose of securing the judiciary's independence. ${ }^{55}$ Judging by the results, the Council members often convey the political preferences of the party that nominated them. Indeed, the voting patterns within the Council attest to a divide between the members considered progressive and those labeled conservative. ${ }^{56}$ The media and public opinion also tends to identify the Council members with the corresponding political party.

Moreover, after serving their mandate, members of the Judicial Council are sometimes appointed to other constitutional bodies or embark on political careers. ${ }^{57}$ The easy transition from the judicial career to politics and back, particularly for Judicial Council members, is concerning from the perspective of judicial independence. For example, the current Minister of Defense is a former judge who in the 1990s served as State Secretary in the Ministry of Internal Affairs (1994-1996), and then became a Supreme Court judge in 2004. In 2008 she was appointed to the Judicial Council and returned to the Supreme Court in 2013, before running in the 2016 general elections as the Socialist Party's second candidate to represent Madrid. Moreover, the Minister of Internal Affairs is a judge of the National Audience, who in 2013 had been appointed to the Judicial Council. Ultimately, the current situation erodes the perception of the Council's independence, and by extension that of the judiciary as a whole.

In order to curtail the risks of politicization, several scholars have called for a reform of the appointment procedure for members from the judiciary and returning to the original

\footnotetext{
${ }^{53}$ Four from Asociación Profesional de la Magistratura and five from Jueces Para la Democracia.

${ }^{54}$ Íñiguez Hernández, supra note 5, at 150.

${ }^{55}$ Ortuño Muñoz, supra note 32 , at121.

${ }^{56}$ Elvira Perales, supra note 15, at 48; îniguez Hernández, supra note 5, at 149; Íñiguez Hernández, supra note 36 , at 336-337.

57 Íñiguez Hernández, supra note 5, at 149.
} 
system in which the judicial members were appointed by their peers. ${ }^{58}$ Indeed, this is the system followed in countries that have similar bodies, such as France, Italy, and Portugal. ${ }^{59}$ Also, Recommendation CM/Rec(2010)12 of the Committee of Ministers of the Council of Europe on Judges: independence, efficiency and responsibility endorsed selecting no fewer than half of the members of judicial councils from judges nominated by their peers from all levels of the judiciary with respect for pluralism inside the judiciary in order to protect those bodies' independence. Along the same line, the 2018 GRECO Report reiterated its view that "political authorities shall not be involved, at any stage, in the selection process of the judicial shift." 60

In our view, the election of the twelve judges by peers certainly poses several advantages: First, the system of appointment would be more congruous with the constitutional design, as the Constitutional Court indicated in 1986. Second, it would contribute to decentralizing the power of appointment, which is now concentrated in the hands of Parliament, by incorporating another actor: the judiciary itself. In this way, the stark correlation in the eyes of the public opinion of Council members with the political parties who proposed them would be mitigated, if not eliminated. Third, the judges governed by the Council would directly participate in the election of those responsible for appointing, promoting, and monitoring them. The Council is not a representative institution as such, but the participation of the judges in appointing Council members could result in a Council more sensitive to the concerns of judges than those of political parties and thus contribute to the legitimacy of this body not only in the eyes of the judges themselves but also in the public at large.

At the same time, direct election by the judiciary would pose problems, such as the risk of corporativism and domination by judicial associations, which might reproduce the ideological divide that we seek to avert. Hence the system of election should attempt to avoid the dominance of judicial associations by offering equal opportunities of participation to all. Moreover, the appointment process should embrace pluralism and diversity in terms of geographic origin and seniority in the judicial career. Regarding the most recent renewal in 2013, among the appointed candidates not one judge was from a one-person judicial body, and four were Supreme Court judges. ${ }^{61}$ To offer an example of how this might be done, Presno Linera has proposed a voting system in which, out of

\footnotetext{
${ }^{58}$ Serra Cristóbal, supra note 17, at 311-317.

${ }^{59} / d$. at 308-309.

${ }^{60} 2018$ GRECO Report, supra note48, para. 37.

${ }^{61}$ Íniguez Hernández, supra note 5, at 150.
} 
twelve members, judges would cast their vote for only eight, and the twelve with the highest number of votes would be elected. ${ }^{62}$

Given the lack of political will to institute selection of the judicial members by their peers, other measures could be taken to improve the current situation in the meantime. First, to ensure that the Council's composition does not reflect the particular configuration of Parliament at the time the Council is renewed, the selection process could be staggered so the Council is renewed in portions. ${ }^{63}$ Since each mandate lasts five years, half the Council could be renewed every two and a half years. Second, to scale down the importance of judicial associations and room for discretion in Parliament, the nomination of judicial candidates could be delegated to the administrative chambers of the Supreme Court, the National Audience, and the High Courts of Justices. ${ }^{64}$ The jurists could be proposed by relevant bodies such as bar associations or universities. ${ }^{65} \mathrm{In}$ addition, the transparency of the parliamentary deliberations could be improved by publishing the candidates' CVs and holding public hearings. ${ }^{66}$ This would allow public scrutiny by civil society, which could also diminish the importance of the candidates' partisan or corporate allegiances. ${ }^{67}$

\section{Internal working dynamics: the Permanent Commission}

Doubts over the Judicial Council's independence may also arise from the Council's internal working dynamics. The 2013 reform introduced an important change regarding the structure of the Council that could affect its independence. Prior to 2013, all Council members were permanent and sole devotion to the Council, to the exclusion of any other professional activity, was required. Then Organic Law 4/2013 concentrated Council powers in a Permanent Commission of five members and the President. ${ }^{68}$ At present, only the members of the Permanent Commission are full-time. At the same time, the legislative reform has further strengthened the role of the Permanent Commission to the detriment

\footnotetext{
${ }^{62}$ Miguel Ángel Presno Linera, Normas y Formas de Gobierno Judicial, XXVII CONGRESO DE JUECES PARA LA DeMOCRACIA. UNA JUSTICIA EN CONFIANZA (2017). See also the proposal by Serra Cristóbal, supra note 17, at 311-317.

${ }^{63}$ Serra Cristóbal, supra note 17, at 306.

${ }^{64}$ Bustos Gisbert, supra note 10 , at 30

${ }^{65}$ Serra Cristóbal, supra note17, at 319.

${ }^{66}$ Up to now, only the jurists go through parliamentary hearings. Serra Cristóbal, supra note17, at 320; López Aguilar, supra note52, at 31

${ }^{67}$ López Aguilar, supra note52, at 31.

${ }^{68}$ Íñiguez Hernández, supra note 36, at 334.
} 
of the Plenary. ${ }^{69}$ Except for discretionary appointments and the enactment of regulations and sanctions, the decisions of the Permanent Commission may not be appealed before the Plenary, and the competences of the Plenary are limited to those listed in Article 499 LOPJ.

Only the position of the full-time members on the Permanent Commission is exclusive and incompatible with the exercise of other administrative responsibilities in the judicial field, whereas part-time members now carry on their regular professional activities, be it as judges, lawyers, or otherwise. In addition, part-time members only receive per diem compensation for their attendance of the Plenary or the corresponding Commission activities, instead of a full salary. ${ }^{70}$ As Íñiguez Hernández has argued, the reform enhances the role of the President and creates two tiers of Council members. ${ }^{71}$

The main reasons for this reform was improving the Council's good administration and economic efficiency. It was also meant to maintain proximity between Council members and the spheres over which they are to govern. Nonetheless, the reform has been heavily criticized. $^{72}$ Indeed, its compatibility with the constitutional design is dubious. ${ }^{73}$ While it might be wise to reduce the number of Council members for reasons of efficiency, this would require a constitutional amendment. ${ }^{74}$ Still, making some of the members part-time can be regarded as a masked constitutional change.

Moreover, making judges in active service part-time members of the Council clashes with the exclusivity clause of the judicial function, ${ }^{75}$ and the prohibition on exercising other public functions. ${ }^{76}$ Indeed, the Socialist congressional deputies challenged the creation of part-time Council members by Organic Law 4/2013 before the Constitutional Court, whose decision is still pending.

${ }^{69}$ Francisco Javier Donaire Villa, La Renovada Configuración de la Comisión Permanente del Consejo General del Poder Judicial tras la Ley Orgánica 4/2013, in INDEPENDENCIA JUDICIAL Y ESTADO CONSTITUCIONAL. EL GOBIERNO JUDICIAL 51 (Luis Aguiar de Luque ed., 2016).

${ }^{70}$ Article 584 bis LOPJ.

${ }^{71}$ Íñiguez Hernández, supra note 5, at 151; îñiguez Hernández, supra note 36, at 333.

${ }^{72}$ Gerpe Landín \& Cabellos Espiérrez, supra note 15, at 24-25; Íñiguez Hernández, supra note 36, at 333.

${ }^{73}$ Diego íñiguez Hernández, supra note5, at 155.

${ }^{74}$ Murillo de la Cueva, supra note 52 , at 36.

${ }^{75}$ Constitution Article 117(4).

${ }^{76}$ Constitution Article 127. 
Ultimately, part-time service may not only undermine the independence of the Council, but also the independence and impartiality of the individual judges who continue their regular jurisdictional functions. ${ }^{77}$ The perception of the independence and impartiality of judges in active service could suffer from association with the political party that supported their appointment as Council members. As for the non-judicial members, they will have to address the tension between their regular and Council activity. For example, lawyers will have to manage the tension between their counseling and representation of litigants before the courts and their role as decision-makers on sensitive issues including the promotion and the discipline of judges.

Moreover, this arrangement is at odds with the guidelines of the Consultative Council of European Judges ${ }^{78}$, which point out that "full-time attendance means a more effective work and a better safeguard of independence." ${ }^{79}$ The 2013 GRECO Report echoed these concerns, arguing that "The change in approach has reportedly been justified on efficiency grounds, but some in the profession argue that this reduces the work capacity of the [Council] and further weakens its independence." ${ }^{80}$ It added that "given the key decisionmaking role that the [Council] plays in vital areas of the judiciary, including on appointments, promotion, inspection and discipline concerning judges, it is crucial that this body is not only free, but also seen to be free from political influence. When the governing structures of the judiciary are not perceived to be impartial and independent, this has an immediate and negative impact on the prevention of corruption and on public confidence in the fairness and effectiveness of the country's legal system." 81

\section{Discretionary appointments to high judicial positions}

Judicial promotion is among the functions that the Constitution attributes to the Council. As mentioned above, the Council enjoys a significant degree of discretion regarding the appointment of judges to higher courts and presidency positions. This discretionary power could directly affect the perception of independence of the judiciary as a whole as well as the independence and impartiality of individual judges. ${ }^{82}$ For instance, judges who want to

\footnotetext{
${ }^{77}$ Bustos Gisbert, supra note 10 , at 30.

${ }^{78}$ Opinion no.10(2007) of the Consultative Council of European Judges (CCJE) to the attention of the Committee of Ministers of the Council of Europe on the Council for the Judiciary at the service of society.

${ }^{79} / d$. para. 34.

${ }^{80}$ Group of States against Corruption, Fourth Evaluation Round. Corruption Prevention in respect of members of Parliaments, judges and prosecutors, GRECO Eval IV Rep (2013) 5E, Strasbourg, 2-6 December 2013, para. 79.

${ }^{81} / d$. para. 80

${ }^{82}$ Gómez Fernández, supra note33, at 97-100.
} 
be promoted might curry the favor of certain political parties by adopting their positions or otherwise making their ideological or political opinions known. This is one way that political factors might unduly affect the promotion of judges and interfere with adjudication. ${ }^{83}$

The politicization of the Council could even make political contacts more important for obtaining positions at the peak of the judiciary. ${ }^{84}$ Similarly, those who belong to the most powerful judicial associations also stand better chances for promotion because of the weight of the judicial associations in the selection of Council members. ${ }^{85}$ Several scholars have already recognized the importance of ideological and personal proximity in the promotion to high judicial positions. ${ }^{86}$ For instance, in 2014, the clash between progressive and conservative Council members spilled into the press when two conservative judges were appointed to the Supreme Court. In fact, one of the judges was a former Council member, who at that time compared same-sex marriage to the union of a person with an animal. $^{87}$

Besides political polarization, the patterns of appointment also show troubling cleavage in terms of gender and geography.

Percentage of women judges in the Supreme Court by Chamber (2018)

\begin{tabular}{|l|l|l|l|l|}
\hline $\begin{array}{l}\text { Civil } \\
\text { (First } \\
\text { Chamber) }\end{array}$ & $\begin{array}{l}\text { Criminal } \\
\text { (Second } \\
\text { Chamber) }\end{array}$ & $\begin{array}{l}\text { Administrative } \\
\text { (Third Chamber) }\end{array}$ & $\begin{array}{l}\text { Labor } \\
\text { (Fourth } \\
\text { Chamber) }\end{array}$ & $\begin{array}{l}\text { Military } \\
\text { (Fifth } \\
\text { Chamber) }\end{array}$ \\
\hline $10 \%$ & $7,1 \%$ & $12,1 \%$ & $33 \%$ & $12,5 \%$ \\
\hline
\end{tabular}

Source: Rafael Bustos Gisbert, Sesgos en la composición de los altos tribunales: género y procedencia. $^{88}$

${ }^{83}$ Eva Desdentado Roca, Los Problemas del Control de Discrecionalidad en los Nombramientos de Altos Cargos Judiciales por el Consejo General del Poder Judicial. Un Análisis Crítico, 139 ReVISTA ESPAÑola de DeReCHO ADMINISTRATIVO (2008).

${ }^{84}$ Perfecto Andrés Ibáñez, Racionalizar y Moralizar la Política de Nombramientos, 52 JUECES PARA LA DeMOCRACIA $12-$ 18 (2005).

${ }^{85}$ Serra Cristóbal, supra note17, at 317.

${ }^{86}$ Bustos Gisbert, supra note10, at 37; López Aguilar, supra note52, at 38-39; íniguez Hernández, supra note5, at 153.

${ }^{87}$ https://politica.elpais.com/politica/2014/04/27/actualidad/1398623319_970402.html

${ }^{88} \mathrm{http}: / /$ agendapublica.elperiodico.com/sesgos-en-la-composicion-de-los-altos-tribunales-genero-y-procedencia/ 
Only in the Labor Chamber was the percentage above 13\%. Moreover, none of the female judges held supervisory positions (President, Vice-president, or Chamber President). Regarding the judges' origin, considering the position they held before their appointment to the Supreme Court reveal the following distribution:

\section{Autonomous Community of prior office of Supreme Court judges}

\begin{tabular}{|l|l|l|l|}
\hline Madrid: 40 & Andalusia: 9 & Catalonia: 8 & Castile \& Leon: 4 \\
\hline Valencia: 4 & Galicia: 3 & Castile la Mancha: 3 & Murcia: 2 \\
\hline Canary Islands: 1 & Aragon: 1 & Asturias: 1 & Basque Country: 1 \\
\hline Extremadura: 1 & Cantabria: 1 & $\begin{array}{l}\text { Balearic Islands, La } \\
\text { Rioja, Navarre: 0 }\end{array}$ & \\
\hline
\end{tabular}

Source: Rafael Bustos Gisbert, Sesgos en la composición de los altos tribunales: género y procedencia. $^{89}$

This table shows that the majority of the judges appointed to the Supreme Court were already in Madrid (50,6\%). The next largest groups of judges came from Andalusia and Catalonia (11,3\% and $10,1 \%$, respectively). There is a clear geographical bias in the sense that about half of the Supreme Court judges were selected among judges who were already in Madrid.

The current legal framework for and practice of appointing judges may very well impair judicial independence. ${ }^{90}$ In addition to the legislative reforms mentioned above, and more importantly from the perspective of practical impact, ${ }^{91}$ in 2006 the Supreme Court issued a judgment representing a shift in its case-law. ${ }^{92}$ The Supreme Court asserted the power to revise the appointments made by the Judicial Council setting the principles of merit and capacity as limits to the Council's discretion. ${ }^{93}$ The Supreme Court required that the Council decisions reflect the proper motivations in order to avoid arbitrariness. It argued that the confidence of the public was at stake.

\footnotetext{
${ }^{89} \mathrm{http}: / /$ agendapublica.elperiodico.com/sesgos-en-la-composicion-de-los-altos-tribunales-genero-y-procedencia/

${ }^{90}$ Gómez Fernández, supra note33, at 98.

${ }^{91}$ ld. at $75-79$.

${ }^{92}$ STS 3171/2006, 29 May 2006.

93 Juan Igartua Salaverría, Motivación de Nombramientos Discrecionales: Posterioridades de la STS 3171/2006, caso Gómez Bermúdez, 58 JUECES PARA LA DEMOCRACIA23 (2007).
} 
The Judicial Council subsequently passed Regulation 1/2010, 25 February 2010, on the provision of discretional positions in judicial bodies, in order to make the criteria to be followed more transparent and avoid arbitrariness. The Regulation distinguished between positions of jurisdictional and administrative nature (or both), and listed the merits to be considered for each type of appointment. For instance, regarding the judges for the Supreme Court, the selection criteria include the length of active service, experience in the jurisdictional field of destination, length of service in collegiate judicial bodies, and the number of especially relevant judicial decisions and their technical quality. Regarding administrative positions, the criteria include previous participation in administrative chambers of courts and the candidates' proposed program of action for the specific position.

Furthermore, Regulation $1 / 2010$ contains the procedure to be followed, which also incorporated new elements for greater transparency: the vacancies are to be announced in the Official Bulletin of the State, and the call for applications is to include the merits that will be taken into consideration. The candidates' applications are to demonstrate fulfillment of the formal requirements and the criteria identified in the call. With regard to vacancies for managerial positions, ${ }^{94}$ a public hearing is to be held before the Judicial Council in which the candidates are to explain and defend their professional experience and accomplishments, with special reference to the merits indicated in the call and, when relevant, the corresponding action program they propose.

Media professionals accredited before the Judicial Council are allowed to attend and record these public hearings, though the presence of the general public and media maybe limited in extraordinary circumstances, for instance after taking into account the principle of proportionality and the possibility that other rights and interests must be protected. ${ }^{95}$

The Permanent Commission is to select three candidates and submit a reasoned resolution to the Plenary of the Judicial Council. The members of the Plenary may consider candidates who were rejected by the Permanent Commission in their final decision. The final selection must also be duly reasoned, a requirement that is fundamental in light of potential appeal to the Supreme Court. ${ }^{96}$

\footnotetext{
${ }_{94}$ In 2013, the public hearing was extended also to the candidates to judicial positions at the Supreme Court among jurists of recognized competence, Decision of 12 March 2013, Plenary of the General Council of the Judiciary to modify Regulation 1/2010, 25 February 2010, on the provision of discretional positions in judicial bodies.

${ }^{95}$ Article 16(3)(b) Regulation 1/2010.

${ }^{96}$ JUAN IgARTUA SALAVerRía, La MotivaCión en LOS Nombramientos DisCRECIONALES (2007).
} 
Even though the case law of the Supreme Court and Regulation 1/2010 have improved the transparency and objectivity of the Council in terms of appointment and promotion, ${ }^{97}$ these processes remain highly discretional. Because the weight of each criterion is not specified, the Council enjoys a broad margin of discretion in assessing and balancing them.

Indeed, the 2013 GRECO Report "recommended that objective criteria and evaluation requirements be laid down in law for the appointment of the higher ranks of the judiciary, i.e. Presidents of Provincial Courts, High Courts of Justice, the National Court and Supreme Court judges, in order to ensure that these appointments do not cast any doubt on the independence, impartiality and transparency of this process. ${ }^{198}$ In 2018, the GRECO Report "noted the lack of any legislative development to lay down objective criteria and evaluation requirements for the higher ranks of the judiciary." It concluded, therefore, that its recommendation had not been implemented. ${ }^{99}$

Several analysts have called for more transparent, objective criteria and procedures. The evaluation of candidates could be performed through objective tests, by asking them to draft judgments for hypothetical or real cases, for example, and mechanisms for continuing evaluation could be introduced. Also, having an independent commission evaluate the candidates' merits prior to the decision by the Council would make the process more objective. ${ }^{100}$

In sum, there are several reasons to question the independence of the Council: the process of appointment that is dominated by the main political parties and judicial associations; the concentration of functions in a reduced Permanent Commission; and the Council's broad margin of discretion for high judicial appointments. The Council's politicization threatens its capacity to secure external judicial independence and the perception of the judiciary's independence. At the same time, at the level of individual judges, there is no clear evidence that their decisions consistently favor particular actors or that they broadly lack independence and impartiality. ${ }^{101}$ Indeed, the 2013 GRECO Report emphasized the divergence between the assessment of the independence of individual judges, and of the independence of the Council: "while the independence and impartiality of individual judges and prosecutors have been broadly undisputed to date, much controversy

\footnotetext{
${ }^{97}$ Murillo de la Cueva, supra note 52, at 25.

${ }^{98} 2013$ GRECO Report, supra note80, para. 39.

${ }^{99} 2018$ GRECO Report, supra note48, para. 40.

${ }^{100}$ Andrés Ibáñez, supra note84, at 13-15; Luis Rodríguez Vega, La independencia judicial a prueba, https://laclavejudicial.org/2018/02/21/la-independencia-judicial-a-prueba/

${ }^{101}$ Murillo de la Cueva, supra note 52, at 24-25, 27.
} 
surrounds the issue of the structural independence of the governing bodies of the judiciary and the prosecutorial service - the primary concern being the appearance that partisan interests could penetrate judicial decision-making processes."

\section{The disciplinary regime and other forms of judicial accountability}

Despite increasing interest regarding judicial accountability, ${ }^{103}$ there is little doubt that this notion remains elusive. ${ }^{104}$ Accountability can be understood in broad or restrictive terms. Bovens distinguished two primary notions of accountability: as a virtue and as a mechanism. As a virtue, accountability is employed as a normative concept, as a set of standards to guide the behavior of actors. As a mechanism, accountability involves "a relationship between an actor and a forum, in which the actor has an obligation to explain and to justify his or her conduct, the forum can pose questions and pass judgment, and the actor may face consequences." ${ }^{105}$

Next we will focus on the more restricted notion of judicial accountability as a mechanism. From that perspective, a range of implications inherent in the notion of accountability must be teased out: to whom should judges be accountable and which supervisory or control procedures should be implemented? What are the standards against which judges may be held accountable? And what are the consequences that might follow?

\section{The disciplinary regime}

From a legal perspective, the disciplinary regime for judges can be understood as a form of accountability in a strict sense. As such, to whom are judges accountable? According to the Constitution, the Judicial Council has the formal power to hold the judges accountable through the inspection program and the disciplinary regime. ${ }^{106}$ That is why the Council, not political bodies, initiate disciplinary proceedings against judges. Also, Administrative chambers and court presidents are granted inspection and disciplinary powers.

\footnotetext{
1022013 Greco Report, para. 3.

${ }^{103}$ Stephen B. Burbank, Judicial Independence, Judicial Accountability, and Interbranch Relations, 95 THE Georgetown LaW Journal909 (2007); Daniela Piana, Judicial Accountabilities in NeW Europe: From Rule of LaW to

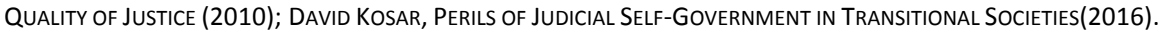

104 Francesco Contini \& Richard Mohr, Reconciling Independence and Accountability in Judicial Systems, 3(2) UTRECHT LAW REVIEW 26, 26-27 (2007).

${ }^{105}$ Mark Bovens, Two Concepts of Accountability: Accountability as a Virtue and as a Mechanism, 33 WEST EUROPEAN POLITICS 946 (2010).

${ }^{106}$ Constitution Article 122(2).
} 
As mentioned above, Organic Law 4/2013 introduced several changes regarding the control of disciplinary proceedings. The Prosecutor is to receive complaints about judicial organs and undertake the instruction procedure. The power to conclude the proceedings and adopt sanctions depends on the qualification of the facts. For minor offenses, the competent bodies are the administrative chambers of courts or their Presidents, depending on the sanction. For serious or very serious offenses, the competent body is the Council's Disciplinary Commission, with the exception of those cases in which the Prosecutor proposes the judge's removal, in which case the resolution corresponds to the Plenary of the Council. It should be remembered that the members of the Disciplinary Commission are now part-time Council members, a circumstance that may undermine the perception of independence. ${ }^{107}$

Next, for what offenses and what are the standards against which judges may be held to account? Judges must respond for actions taken in the exercise of their functions, yet they cannot be disciplined for the exercise of jurisdictional functions, for such sanctions would compromise their independence. ${ }^{108}$ The interpretation and application of the law cannot be the object of the disciplinary power. Actionable offenses are classified in three groups: very serious (for example, affiliation to political parties or trade unions, the unjustified and reiterated delay of proceedings, abuse of office to obtain favorable treatment from the authorities); serious (including abuse of authority or lack of consideration for citizens and officials who take part in the proceedings, or unjustified delays); and minor (such as the failure to meet procedural deadlines in issuing decisions). ${ }^{109}$

Finally, what are the consequences or effects that might follow? In the context of the disciplinary regime, the effects take the form of sanctions. According to Article 420 LOPJ, the sanctions that can be imposed upon judges are: warnings; fines up to 6000 Euros; forced transfer to another court; suspension from office for up to 3 years; and removal. According to LOPJ, the duration of the disciplinary proceedings is limited to 6 months. ${ }^{110}$ In 2013, the GRECO Report recommended extending the limit, ${ }^{111}$ since the short time span had given rise to a number of decisions of the Supreme Court overturning the sanction of

\footnotetext{
${ }^{107}$ Gerpe Landín \& Cabellos Espiérrez, supra note 15.

${ }^{108}$ Luis López Guerra, Modelos de Gobierno de los Jueces, 1 PARLAMENTO Y CONSTITUCIÓN. ANUARIO 14 (1997).

${ }^{109}$ Articles 417-419 LOPJ.

${ }^{110}$ Article 425(6) LOPJ.

${ }^{111} 2013$ GRECO Report, supra note 80, recommendation viii.
} 
the Council on the grounds that the relevant disciplinary proceedings had not respected the statute of limitations, but this recommendation has not been implemented. ${ }^{112}$

Information about the frequency and intensity of disciplinary sanctions is provided in the Council's Annual Report to Parliament. According to the 2017 Report, ${ }^{113}$ the Prosecutor submitted twenty-five proposals of sanctions in 2016: ten were dismissed and in fifteen instances sanctions were imposed. The main reasons for dismissal were failure to prove responsibility or lapse of the statute of limitations. Most of the sanctions were for unjustified delays. These statistics were very similar in the previous year's report.

\section{Code of judicial ethics}

Taking a broader perspective, we might consider other instruments of judicial accountability, such as judicial codes of conduct or ethics. In December 2016, the Plenary of the Judicial Council released a document on "Principles of Judicial Ethics"114 adopted in response to international instruments on the subject, such as the Bangalore Principles of Judicial Conduct (2002); or the Council of Europe's Recommendation of the Committee of Ministers CM/R(2010)12 to the member states on Judges: independence, efficiency and responsibilities. Moreover, the 2013 GRECO Report recommended that Spain adopt a code of conduct for judges.

The "Principles of Judicial Ethics" contain two main sections. The first enumerates the principles to be followed: independence, impartiality, integrity, courtesy, diligence, and transparency. Effort is made to specify the requirements that derive from these general principles. The second section foresees the creation of a Commission of Judicial Ethics whose functions would include issuing opinions in response to the requests made by courts' administrative chambers, judicial associations or individual judges, as well as drafting reports on issues of general interest and promoting the principles of judicial ethics. The Commission is to be composed of seven members: one judge, three magistrates, two magistrates of the Supreme Court, and one professor with recognized expertise in this domain. The judicial members of the Commission are to be elected by their peers who would in turn elect the lay member.

The creation of this Commission, however, is still pending, and the impact of this document has been scarcely noticeable in practice. Indeed, its Preamble distinguishes the disciplinary regime from judicial ethics, and understands that the latter as voluntary and

\footnotetext{
${ }^{112} 2018$ GRECO Report, supra note 48, para. 52.

${ }^{113} 2017$ Annual Report of the General Council of the Judiciary, at 39.

${ }^{114}$ http://www.poderjudicial.es/cgpj/es/Temas/Transparencia/Buen-Gobierno-y-Codigo-etico/Codigo-Etico/
} 
not as entailing legal responsibility. The principles are conceived as ex ante standards to guide judicial behavior, but lack any specific effect in case of breach. The Commission of Judicial Ethics never has more than a consultative nature, but it could at least contribute in solving ethical dilemmas and communicating to the broader public through its reports.

\section{Democratic accountability}

Finally, from the standpoint of democratic accountability, to what extent is the judiciary as a whole accountable to Parliament? ${ }^{115}$ Judges are charged with applying the law, and only the law, to the resolution of the individual cases brought before them. By doing so, the application of the law becomes a source of democratic legitimacy. Nonetheless, the law is not completely determinate and its interpretation thus leaves room for discretion. There is sometimes a risk that judges read their own values into the law. ${ }^{116}$ Judges also play a part in the creation, modification or reinforcement of norms through adjudication. ${ }^{117}$ Any form of direct control, however, of Parliament over judicial decisions would aggrieve judicial independence, which is unnecessary since Parliament has the power to control courts in other ways, namely through legislative amendment.

All the same, we might wonder whether some form of accountability of the Judicial Council before Parliament could have democratic benefits. On the one hand, the election of the Council members by the Parliament could contribute to the Council's democratic legitimacy at an initial moment. ${ }^{118}$ Nonetheless, as argued above, the practice of appointing judges along ideological lines has impaired the Council's independence.

Regarding the functioning of the Judicial Council, the Annual Report that the Council must submit to Parliament could be regarded as a soft form of accountability, even though it entails no specific effects or consequences. ${ }^{119}$ At most, Parliament may summon the President of the Supreme Court for questioning about the Report. ${ }^{120}$ Still, the presentation

\footnotetext{
${ }^{115}$ Mario Hernández Ramos, El Cambio de Paradigma en el Control del Poder Judicial como Instituciónen España. De la Responsabilidad Judicial a la Judicial Accountability, in INDEPENDENCIAJUDICIAL Y ESTADO CONSTITUCIONAL. EL ESTATUTO DE LOS JUECES 149, 165-175 (Maribel González Pascual \& Joan Solanes Mullor eds., 2016).

${ }^{116}$ Aida Torres Pérez, In Nobody's Name: A Checks and Balances Approach to International Judicial Independence, MPIL Research Paper Series No. 2017-3.

${ }^{117}$ Armin Von Bogdandy\& Ingo VenzKe, IN Whose Name? A Public LaW Theory of InternationalAdjudication 12-14 (2014).

${ }^{118}$ Luis López Guerra, La Legitimidad Democrática del Juez, 1 CUAdernos de DeRECHO PúBLICO 43, 70 (1997).

${ }^{119}$ Article 563(1) LOPJ.

${ }^{120}$ Article 563(3) LOPJ.
} 
of the Report might be conceived as an opportunity for dialogue between the Parliament and the Judicial Council about the state of the judicial system, its main problems and needs. The current President of the Council, Carlos Lesmes, on the occasion of his presentation of the Annual Report of 2012 before the congressional Justice Commission, declared his wish to initiate a new stage of interaction between the judiciary and Parliament through new mechanisms of communication not limited to the presentation of the Annual Report in order to enhance institutional collaboration and dialogue. ${ }^{121}$ Notwithstanding, Organic Law 4/2013 adopted a restrictive approach in Article 564 LOPJ, according to which, except for the presentation of the Annual Report mentioned above, the President of the Supreme Court and the Council members are under no obligation to appear before Parliament to discuss their functions.

\section{The role of the Judicial Council in promoting transparency}

Transparency facilitates the operation of accountability mechanisms by ensuring the relevant information is available, but transparency is not an accountability mechanism in and of its own. ${ }^{122}$ Transparency is not an end in itself, and its value in the judicial realm has various dimensions: transparency enables public scrutiny of the judicial activity, which might further public debate and thereby enhance public confidence. Transparency might even act as a counterweight to potential sources of undue influence or interference by other public authorities by shedding light on appointment procedures or the internal organization of courts. Hence, transparency could potentially mitigate or counteract constraints on judicial independence emanating from external actors by providing the public at large with essential information. ${ }^{123}$

What has been the impact of the Judicial Council with regards transparency? In recent years, the Judicial Council has taken pains to improve transparency surrounding its own activity and that of the judiciary as a whole. ${ }^{124}$ Indeed, transparency has become one of the primary guiding principles for the current Council. ${ }^{125}$ The Permanent Commission even created a Working Group on Transparency on 7 January 2014 that was renewed in $2016 .{ }^{126}$

\footnotetext{
${ }^{121}$ Hernández Ramos, supra note115, at 173.

${ }^{122}$ Kosar, supra note103, at 102.

${ }^{123}$ Torres Pérez, supra note3, at 477-478.

${ }^{124}$ Hernández Ramos, supra note115, at 178-180.

${ }^{125} 2017$ Annual Report to Parliament, http://www.poderjudicial.es/cgpj/es/Poder-Judicial/Consejo-General-delPoder-Judicial/Actividad-del-CGPJ/Memorias/

${ }^{126}$ http://www.poderjudicial.es/cgpj/es/Temas/Transparencia/Buen-Gobierno-y-Codigo-etico/Grupo-de-Trabajosobre-Transparencia/
} 
In addition, the Council created a Website on Transparency ${ }^{127}$ to facilitate citizen access to information about the Council, its activity, its use of public resources, the reasons for its decisions, and other subjects of public interest. This website includes three main areas: economic and financial information; Council activity; and judicial transparency. Regarding the economic and financial information, the website describes the Council budget and its management and details such as the travel expenses of Council members. It also discloses salaries and the funds approved for the development of external activities.

Regarding the activity of the Judicial Council, the website contains links to Council agreements, agreements with other institutions (national and international), relevant studies, the Annual Report, and the reports on drafts of bills before the legislature. Remarkably, the Council offers specific information on the selection processes for the discretional appointment of judges. For each vacancy, the call, the names of the candidates and their CVs, the videos of the hearings, the proposal of the Permanent Commission, and the Plenary appointment decision are all made available. The CVs and the interviews of rejected candidates are removed on request after two months or, otherwise, after nine months.

As regards the activity of the judiciary, the website includes a directory of all judicial bodies, a dataset on corruption trials; relevant studies and statistics. Also, the Council manages the CENDOJ, a database that compiles all judgments issued by collegiate bodies: the Supreme Court, the National Audience, the High Courts of Justice, and Provincial Courts, as well as selected judgments from lower courts. Furthermore, the Council spurred the creation of transparency websites for several judicial bodies. So far, the following bodies have their own transparency websites: the Supreme Court, the National Audience, and the High Courts of Justice of each Autonomous Community. In sum, the Council has labored to provide the public with broad, easily available information and promote increased transparency regarding judicial activities. The principal shortcoming regarding transparency remains the appointment process for the members of the Council itself.

\section{Judicial self-government and public confidence in the judiciary}

Public confidence in the judiciary is crucial for its sociological legitimacy and, by extension, the proper functioning of the legal system. As Tom Tyler has shown, confidence in the judiciary expressed as institutional legitimacy derives from the positive assessment of procedural fairness rather than from the outcomes of specific cases. ${ }^{128}$ To measure the

\footnotetext{
127 Agreement of the Permanent Commission of 17 March 2015: Portal de Transparencia "José Luis Terrero Chacón": http://www.poderjudicial.es/cgpj/es/Temas/Transparencia/

${ }^{128}$ Tom R. Tyler, Public Trust and Confidence in Legal Authorities: What Do Majority and Minority Group Members Want from the Law and Legal Institutions?, 19(2) BEHAVIORAL SCIENCES AND THE LAW 215 (2001).
} 
impact of the Judicial Council on the perception of the judiciary as a whole in the public opinion from this institutional perspective, we must rely on statistical studies, which are scarce.

In general, the Eurobarometer reveals that more than half of Spain's population tends not to trust the justice system. In the last four years, however, the trend has improved. In 2014, 71\% of the population tended to distrust the justice system, while in November 2017 the percentage was down to $56 \%$.

129

Trust on the justice system in Spain

\begin{tabular}{|l|l|l|l|l|l|l|}
\hline & $\begin{array}{l}2014 \\
\text { (Nov) }\end{array}$ & $\begin{array}{l}2015 \\
\text { (May) }\end{array}$ & $\begin{array}{l}2016 \\
\text { (May) }\end{array}$ & $\begin{array}{l}2016 \\
(\text { Nov) }\end{array}$ & $\begin{array}{l}2017 \\
\text { (May) }\end{array}$ & $\begin{array}{l}2017 \\
\text { (Nov) }\end{array}$ \\
\hline $\begin{array}{l}\text { Tend to } \\
\text { trust }\end{array}$ & $25 \%$ & $35 \%$ & $40 \%$ & $43 \%$ & $37 \%$ & $42 \%$ \\
\hline $\begin{array}{l}\text { Tend not } \\
\text { to trust }\end{array}$ & $71 \%$ & $62 \%$ & $56 \%$ & $53 \%$ & $62 \%$ & $56 \%$ \\
\hline $\begin{array}{l}\text { Don't } \\
\text { know }\end{array}$ & $4 \%$ & $3 \%$ & $4 \%$ & $4 \%$ & $1 \%$ & $2 \%$ \\
\hline
\end{tabular}

Source: Eurobarometer. ${ }^{130}$

In addition to the statistics compiled by the European Union, the General Council of the Spanish Bar (Consejo General de la Abogacía Española) carries out two types of statistical studies on the perception of justice in the Spanish society: the external barometer, addressed to the civil society at large; and the internal barometer, which focuses on the opinion of lawyers. ${ }^{131}$ The last published studies date from 2015.

According to the internal barometer, $91 \%$ of the lawyers agreed with the assertion that "[g]overnments, of all ideologies, are generally more interested in trying to control justice or to influence it, than to launch a profound reform on its functioning in order to modernize it and making it fully efficient" (Question 1); and 92\% agreed that "[t]he attempt of the several parties to control the Judicial Council hinders the efficient development of its functions" (Question 2). Hence, there is a widespread opinion among

\footnotetext{
${ }^{129}$ The question about the trust on justice and the national legal system was only introduced in 2014.

${ }^{130} \mathrm{http}: / /$ ec.europa.eu/commfrontoffice/publicopinion/index.cfm/Survey/index\#p=1\&instruments=STANDARD

${ }^{131}$ http://www.abogacia.es/2015/11/25/barometros-de-la-abogacia/
} 
those who interact on a daily basis with the courts that the Judicial Council is under the influence of the main political parties. This perception has tended to increase over time:

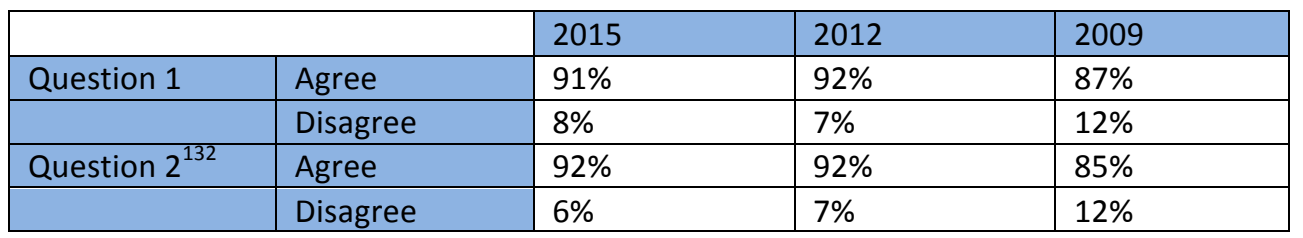

Source: Internal barometer of the General Council of the Spanish Bar. ${ }^{133}$

According to the external barometer, $81 \%$ of the respondents agreed upon that "[a]II governments, of whatever color, have been more interested in controlling justice than providing the sufficient means in order to improve it"; and 90\% concur that"[i]t is urgent to reach a state agreement about the justice system that protects it in a clear and credible form before influences and interferences of a political nature."

Citizens were also questioned about the role of the Judicial Council. ${ }^{134}$ The results reveal general distrust of the citizens on the Council. More than half believe that the Council does not fulfill its main purpose of ensuring judicial independence. Almost $80 \%$ believe that high judicial appointments by the Council respond to political or personal motivations; and $88 \%$ hold that the Council became too susceptible to political influence after the reform that introduced the Permanent Commission. Public confidence has also trended downward over time.

\footnotetext{
${ }^{132}$ In 2009, the question was a bit different: "The General Council of the Judiciary has become so politicized that it can hardly manage in an efficient and impartial way the functioning of the Judiciary."

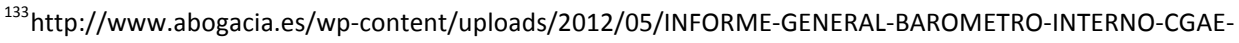
JULIO-2015.pdf

${ }^{134}$ http://www.abogacia.es/wp-content/uploads/2015/07/INFORME-V-BAROMETRO-EXTERNO-CGAENOVIEMBRE-2015.pdf, at 13 [author's translation]
} 


\begin{tabular}{|l|l|l|}
\hline \multicolumn{3}{|l|}{ Do you agree with the following statements about the General Council of the Judiciary? } \\
\hline \multicolumn{1}{|l|}{} & 2015 & 2011 \\
\hline $\begin{array}{l}\text { According to its current organization and functioning with a } \\
\text { Permanent Commission that is responsible for most operations, the } \\
\text { Judicial Council is too susceptible to political influence and } \\
\text { conditions. }\end{array}$ & & \\
\hline Yes & $88 \%$ & $\mathrm{X}$ \\
\hline No & $7 \%$ & $\mathrm{X}$ \\
\hline Neither agree nor disagree & $1 \%$ & $\mathrm{X}$ \\
\hline $\begin{array}{l}\text { The General Council adequately fulfills its function of defending the } \\
\text { independence of judges and courts. }\end{array}$ & & \\
\hline Yes & $31 \%$ & $37 \%$ \\
\hline No & $58 \%$ & $44 \%$ \\
\hline Neither agree nor disagree & $2 \%$ & $5 \%$ \\
\hline $\begin{array}{l}\text { The General Council tends to make decisions about judicial } \\
\text { appointments according to political or personal reasons rather than } \\
\text { relying exclusively on technical and professional factors. }\end{array}$ & & \\
\hline Yes & $79 \%$ & $68 \%$ \\
\hline No & $16 \%$ & $20 \%$ \\
\hline Neither agree nor disagree & $2 \%$ & $2 \%$ \\
\hline
\end{tabular}

Source: External barometer of the General Council of the Spanish Bar. ${ }^{135}$

Hence, lawyers and civil society overwhelmingly believe that political parties seek to control the justice system. The perception of citizens regarding the role of the Council is particularly negative. Yet when individuals were asked about the impartiality of judges (that question was not posed to lawyers), 50\% agreed that in general they tend to be impartial, while $42 \%$ believed that they were not. As such, the level of distrust regarding individual judges is lower than distrust of the Council, but still high.

The perception that the justice system is overly politicized is intimately linked to the Judicial Council and the model it follows for the appointment of its members and the high judicial positions. Every time the Council is renewed, citizens are aware that quotas are negotiated among the main political parties and that the selection is made along ideological lines. For instance, newspapers have published the correlation between progressive and conservative Council members and the parties that appointed them. Regarding appointments to the Supreme Court, the media tends to present the

\footnotetext{
${ }^{135} \mathrm{http}: / /$ www.abogacia.es/wp-content/uploads/2015/07/INFORME-V-BAROMETRO-EXTERNO-CGAENOVIEMBRE-2015.pdf, at 13 [author's translation].
} 
information about new appointments as the result of negotiation between the progressive and conservative members within the Council. This arrangement undermines public confidence in the Council and, by extension, in the judiciary, given the sensitive functions of appointment and discipline with which the Judicial Council is tasked.

Scandals involving the Council have also undermined its image before the public opinion. For instance, in 2012 the press revealed that the President of the Council and the Supreme Court, Carlos Dívar, used public funds to cover the expense of thirty-two trips to the southern coast of Spain that included stays at luxury hotels and meals at expensive restaurants. He claimed that he had taken the trips in his professional capacity as a representative of the Council, but in the end he was nonetheless compelled to resign by the public pressure. ${ }^{136}$

A similarly derisory perception is shared by scholars, who have denounced the politicization of the Council as a consequence of the informal quota system devised by the two main political parties to elect Council members together with the use of the discretional power to appoint high-ranking judicial officers. ${ }^{137}$ In the end, it is urgent to depoliticize the Council, modify the system of appointing their members and the internal process for the appointment of high judicial positions in order to recover public confidence.

\section{Concluding remarks}

The emergence and evolving importance of judicial independence is intimately linked to the principle of the separation of powers. ${ }^{138}$ In the Spirit of Laws, Montesquieu argued for the need to separate the judicial function from the legislative and executive in order to protect liberty: "There is no liberty, if the judiciary power be not separated from the legislative and executive. Were it joined with the legislative, the life and liberty of the subject would be exposed to arbitrary control; for the judge would then be the legislator. Were it joined to the executive power, the judge might behave with violence and oppression." 139

\footnotetext{
${ }^{136}$ https://www.nytimes.com/2012/06/22/world/europe/spains-chief-justice-divar-quits-over-trips.html; https://politica.elpais.com/politica/2012/06/21/actualidad/1340263648_089791.html

${ }^{137}$ Murillo de la Cueva, supra note 52, at 24-26, 32-33; Bustos Gisbert, supra note 10, at 30; íniguez Hernández, supra note 5, at 155 .

${ }^{138}$ Pasquale Pasquino, Prolegomena to a Theory of Judicial Power: The Concept of Judicial Independence in Theory and History, 2 The LAW AND PRActice Of INTERNational COURTS AND TRIBUNALS 14-15(2003).

${ }^{139}$ Montesquieu, THe SPIRIT OF THE LAWs, Book 11, Chapter 6, 157 (1989).
} 
The rationale for the creation of Spanish Judicial Council was tied to ensuring external judicial independence and disempowering influence from the political branches. Notwithstanding, the Judicial Council is itself an institution that does not fit the classical separation of powers into three branches: legislative, executive, and judicial. While the Council is neither part of the executive nor the judicial power, it was instituted for the selfgovernment of the judiciary. Indeed, separation of powers as a principle has evolved over time in the face of the growing institutional complexity to the point that it is no longer understood as a pure tripartite separation (if it ever was). ${ }^{140}$

The strategy for the safeguard of judicial independence consisted of creating and vesting a new institution with the functions related to the appointment, promotion, and discipline of judges that were traditionally under the purview of the executive. Nonetheless, transferring functions to a new institution is doomed to fail as a mechanism for external judicial independence if this new institution falls under the influence of the political branches. In Spain, the Council has been politically captured as a consequence of the method adopted to make appointments and the internal practices of the Council. The successive reforms of the Council have not managed to resolve this problem. As a consequence, the perception among the general public regarding the role of Council and the impact upon the judiciary is as a whole very negative. Nevertheless, as attested by the 2013 GRECO Report, the independence and impartiality of individual judges has not been broadly challenged.

Should then the Judicial Council be abolished? The Council has had a relevant role in promoting transparency, and the result of transferring the Council's functions back to the government would probably be worse in terms of political influence and public perception. In some sense, adopting the institutional option for an ad hoc judicial self-government institution involved creating a sort of interface between the judiciary and the political branches. In Spain, the political capture of that interface prevents it from serving its purpose and that failure has contributed to undermining public confidence in the judiciary as a whole. The institutional design and current practice urgently requires revision. Yet another reform, however, will accomplish nothing unless the political culture of "appropriating" purportedly independent public institutions by the political parties is abandoned.

\footnotetext{
${ }^{140}$ Eoin Carolan, The New Separation of Powers: A Theory of the Modern State (2009); Christoph Möllers, The Three BRANCHES. A Comparative Model of Separation of PoWers (2013).
} 